\title{
Difficulties Faced by Dental House Officers During Clinical Endodontics
}

\author{
Azam Muhammad Aliuddin ${ }^{1}$ \\ BDS \\ Tasleem Hosein ${ }^{2}$ \\ Abubakar Sheikh ${ }^{3}$ \\ Saqib Rashid ${ }^{4}$ \\ Jabeen Zafar Ali \\ BDS, FDS R.C.S. \\ BDS, FCPS \\ BDS, M.Sc, FCPS \\ BDS
}

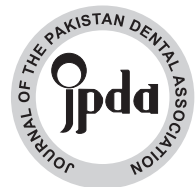

OBJECTIVE: The objective of this study was to determine the difficulties faced by house officers during endodontic procedures and refine the quality of therapy provided to masses.

METHODOLOGY: A detailed survey form was given out to a total of 350 dental house officers, collected from seven different dental institutes in Karachi. A total of 60-80 survey forms were given out to each college, depending on the strength of house officers present, out of which 50 forms, on average, were returned and results were tabulated. The supervisor to house officer ratio recorded on average from these institutes was 1:7. WHO Calculator was used on the sample size of 350 entries and SPSS Version 22 was used to analyze the results.

RESULT: The current study displays that majority of the house officers faced immense difficulties in the cleaning and shaping task of the endodontic procedure such as in cleaning and shaping and less problems were encountered when access opening and initial instrumentation were concerned. The most common difficulty faced by the house officers was that apical perforation resulted during the procedure (51.4\%) followed by loss of estimated WL (51.1\%), ledge formation $(40.9 \%)$, file separation $(39.1 \%)$, whereas using accessory GP while obturations was recorded as the most frequently encountered problem $(56 \%)$.

CONCLUSION: The current study displays the most commonly faced difficulties by fresh dental graduates during their house job. The major difficulties were faced during cleaning and shaping owing to increased incidence of ledge formation, apical perforation and loss of working length. Majority of the cases revealed gutta purcha extruding or short of the apex. Difficulty in administering IANB was also highly noted.

KEYWORDS: Education, Difficulty, House Officers, Clinical Endodontics

HOW TO CITE: Aliuddin AM, Hosein T, Sheikh AB, Rashid S, Ali JZ. Difficulties faced by dental house officers during clinical endodontics. J Pak Dent Assoc 2018;27(4):165-71

DOI: https://doi.org/10.25301/JPDA.274.165

Received: 30 May 2018, Accepted: 02 August 2018

\section{INTRODUCTION}

$\mathrm{D}$ entistry as a profession requires a comprehensive strategy which is mostly a collection of vigorous struggles, persuasion and sufficient clinical exposure. ${ }^{1}$ Endodontics has been widely described as a

1. FCPS Resident, Department of Operative Dentistry, Fatima Jinnah Dental College Karachi, Pakistan.

2. Professor, Department of Restorative Dentistry, Fatima Jinnah Dental College, Karachi.

3. Associate Professor, Department of Endodontics Fatima Jinnah Dental College Karachi, Pakistan.

4. Professor, Department of Operative Dentistry, Fatima Jinnah Dental College Karachi, Pakistan.

5. Demonstrator, Department of Endodontics, Fatima Jinnah Dental College Karachi, Pakistan.

Corresponding author: "Dr. Azam Muhammad Aliuddin” < azam_aliuddin@yahoo.com > troublesome branch of dentistry due to diverse procedures and protocols. Adequate instrumentation, complete removal of chemical debris and satisfactory root canal filling, keeping in mind the anatomical variations of different teeth, guarantee a successful endodontic procedure. ${ }^{2}$

With adequate clinical experience and exposure comes the knowledge to evaluate the likely outcome of a tooth which is scheduled for an endodontic procedure. Apart from rare cases which are termed as high risk conditions, majority of the cases can be managed and prognosis prior to the treatment can be predicted. However, where there are certain factors which are not in control of the operator, a lot of components of a successful root canal depend on the way the operator executes the treatment plan. ${ }^{3}$ 
Lack of early clinical exposure, stressful working environment, a more curriculum based learning, which focuses on more theoretical work rather than a practical approach and an overall compromised student-teacher relationship ${ }^{4}$ are just some of the major factors contributing towards the ongoing fear and generalized discomfort while conducting any dental care procedure. In addition to these, there are conventional limitations faced by dental house officers while performing endodontic treatment, especially by those who have minimal or no previous clinical experience. During Endodontic procedures, each step requires immense care and attention on behalf of the operator, which leads to a generalized lack of self-confidence among house officers who have inadequate clinical exposure and expertise. Previous studies, focusing on the inadequacy of the root canal filling, have shown that a large number of students face problems due to procedural errors.

Previous studies conducted by Mozayeni et $\mathrm{al}^{5}$, Konstantinos Dervenis et $\mathrm{al}^{6}$, Mothanna K. AlRahabia ${ }^{7}$ have allocated many procedural errors as being common during endodontic procedures such as ledge formation $(26 \%)^{5}$, $(10.1 \%)^{6}$, voids $(27.3 \%)^{5},(12.6 \%)^{7}$, overfilling $(15.3 \%)^{5}$, $(21.6 \%)^{6},(24.1 \%)^{7}$, under filling $(23.3 \%)^{5},(49.9 \%)^{7}$ and broken instruments $(0.7 \%)^{6},(9.2 \%) .^{7}$ Transportation was also commonly observed in such studies, $(8.7 \%)^{5},(3.1 \%)^{6}$, $(2.3 \%){ }^{7}$

The study focuses on the routine difficulties faced by dental house officers when performing endodontic procedures and evaluate the reasons for these problems. By thorough evaluation of the issues faced by dental graduates, the goal of this study is to create a more comfortable and stress free clinical environment for the operators, which in return will help improve the quality of oral health care services provided to the community. This study will help improve overall skills and help freshly graduated dental officers overcome fears associated with root canal procedures. Its main objective is to prevent mishaps in the future by evaluating the problems faced by house officers on a daily basis and refine the quality of therapy provided to masses.

\section{METHODOLOGY}

A detailed survey form was given out to a total of 350 dental house officers, collected from seven different dental institutes in Karachi. A total of 60-80 survey forms were given out to each college, depending on the strength of house officers present, out of which 50 forms, on average, were returned and results were tabulated. The supervisor to house officer ratio recorded on average from these institutes was 1:7. Sample size of 350 was calculated using WHO Calculator and results were analyzed using SPSS Version 22.

\section{INCLUSION CRITERIA}

1. All house officers who have completed their house job with a mandatory posting of 2 months in Endodontics Department. 2. Completed at least 15 root canal treatment cases. 3. Both male and female house officers were included. 4. Performed conventional endodontic method.

\section{EXCLUSION CRITERIA}

1. Graduates who had started or were in the middle of their House Job were not included in this study. Graduates who were incompetent in completing their required period of house job were excluded.

2. Cases involving use of only conventional methods of endodontics were included in this study where cleaning and shaping of the root canal was done using Crown-Down technique. Preparations of canals using rotary files were excluded.

3. House officers who did not maintain adequate record of their cases were not included in the study. Minimum requirement for eligibility was 15 endodontic cases performed under direct supervision in the department.

The questionnaire contained 35 questions which were meant to focus on the level of difficulty faced by each dentist during 6 different stages of the treatment. These stages included Anesthesia (3 questions), Pre-operative assessment (6 questions), Chamber opening (5 questions), Working length establishment (3 questions), Cleaning and shaping (11 questions) and Obturation (7 questions). Each response was numbered according to the level of difficulty as shown in Figure.1.

\section{RESULTS}

A total of 350 house officers participated in this research out of which 164 were male (47\%) and 186 were female $(53 \%)$. Descriptive statistics were used to calculate the percentage of difficulty faced by each house officer while performing each task. The results are displayed in tables $1-6$.

According to the results, our study showed that $48 \%$ of house officers faced difficulty in administering effective IANB and $45.7 \%$ found the need to give accessory anesthesia

(Table 1). Time management was another difficulty faced by $42 \%$ of the house officers (Table 2). During access opening $29.1 \%$ of the recorded responses showed difficulties encountered while de-roofing the pulp chamber (Table 3) and $19.4 \%$ had struggled while using the apex locators (Table 4). The highest percentage of difficulty was observed during cleaning and shaping processes (Table 5) with the 
Table 1: Local anesthesia related difficulty

\begin{tabular}{|c|c|c|c|c|c|c|}
\hline \multirow{2}{*}{\multicolumn{2}{|c|}{ QUESTIONS }} & \multicolumn{4}{|c|}{ DIFFICULTY GRADING \% } & \multirow{2}{*}{$\begin{array}{l}\text { DIFFICULTY } \\
\text { GRADING } \\
\text { CRITERIA }\end{array}$} \\
\hline & & NEVER & RARELY & OCCASIONALLY & FREQUENT & \\
\hline 1 & $\begin{array}{l}\text { Difficulty with success of } \\
\text { IANB }\end{array}$ & $8(2.3)$ & $65(18.6)$ & 109 (31.1) & $168(48)$ & \multirow{3}{*}{$\begin{array}{l}\text { Maximum } \\
\text { difficulty in } \\
\text { success of IANB } \\
-48 \% \\
\rightarrow \text { Need for } \\
\text { accessory } \\
\text { anesthesia with } \\
\text { IANB }-45.7 \% \\
\rightarrow \text { Difficulty in } \\
\text { success for } \\
\text { infiltration - } \\
38.6 \%\end{array}$} \\
\hline 2 & $\begin{array}{l}\text { Need for accessory } \\
\text { means of anesthesia with } \\
\text { IANB }\end{array}$ & $37(10.6)$ & $55(15.7)$ & $98(28.0)$ & $160(45.7)$ & \\
\hline 3 & $\begin{array}{l}\text { Difficulty with success of } \\
\text { infiltration }\end{array}$ & $30(8.6)$ & $53(15.1)$ & $132(37.7)$ & $135(38.6)$ & \\
\hline
\end{tabular}

Table 2: Patient related difficulty

\begin{tabular}{|c|c|c|c|c|c|c|}
\hline \multirow{2}{*}{\multicolumn{2}{|c|}{ QUESTIONS }} & \multicolumn{4}{|c|}{ DIFFICULTY GRADING \% } & \multirow{2}{*}{$\begin{array}{l}\text { DIFFICULTY GRADING } \\
\text { CRITERIA }\end{array}$} \\
\hline & & NEVER & RARELY & OCCASIONALLY & FREQUENT & \\
\hline 1 & $\begin{array}{l}\text { Difficulty in } \\
\text { correct diagnosis }\end{array}$ & $190(54.3)$ & $141(40.3)$ & $17(4.9)$ & $2(0.6)$ & \multirow{6}{*}{$\begin{array}{l}\text { Maximum difficulty in } \\
\text { time management }-42 \% \\
\rightarrow \text { Difficulty in pain } \\
\text { management }-34.3 \% \\
\rightarrow \text { Difficulty in patient } \\
\text { counseling - } 31.4 \% \\
\rightarrow \text { Difficulty to } \\
\text { understand preoperative } \\
\text { radiograph }-8 \% \\
\rightarrow \text { Difficulty in rubber } \\
\text { dam placement }-1.7 \% \\
\rightarrow \text { Difficulty in correct } \\
\text { diagnosis - } 0.6 \%\end{array}$} \\
\hline 2 & $\begin{array}{l}\text { Difficulty to } \\
\text { understand } \\
\text { preoperative } \\
\text { radiograph }\end{array}$ & $48(13.7)$ & $167(47.7)$ & $107(30.6)$ & $28(8.0)$ & \\
\hline 3 & $\begin{array}{l}\text { Difficulty in pain } \\
\text { management }\end{array}$ & $29(8.3)$ & $89(25.4)$ & $112(32)$ & $120(34.3)$ & \\
\hline 4 & $\begin{array}{l}\text { Difficulty in } \\
\text { patient counseling }\end{array}$ & $35(10.0)$ & $63(18.0)$ & $142(40,6)$ & $110(31.4)$ & \\
\hline 5 & $\begin{array}{l}\text { Difficulty in } \\
\text { rubber dam } \\
\text { application }\end{array}$ & $38(10.9)$ & $138(39.4)$ & $168(48.0)$ & $6(1.7)$ & \\
\hline 6 & $\begin{array}{l}\text { Difficulty in time } \\
\text { management }\end{array}$ & $35(10.0)$ & $56(16.0)$ & $112(32.0)$ & $147(42.0)$ & \\
\hline
\end{tabular}

Table 3: Chamber (access) opening related difficulty

\begin{tabular}{|c|c|c|c|c|c|c|}
\hline \multirow{2}{*}{\multicolumn{2}{|c|}{ QUESTIONS }} & \multicolumn{4}{|c|}{ DIFFICULTY GRADING \% } & \multirow{2}{*}{$\begin{array}{l}\text { DIFFICULTY GRADING } \\
\text { CRITERIA }\end{array}$} \\
\hline & & NEVER & RARELY & OCCASIONALLY & FREQUENT & \\
\hline 1 & $\begin{array}{l}\text { Difficulty in } \\
\text { adequately De- } \\
\text { roofing the } \\
\text { chamber }\end{array}$ & $26(7.4)$ & $86(24.6)$ & $136(38.9)$ & $102(29.1)$ & \multirow{5}{*}{$\begin{array}{l}\text { Maximum difficulty in } \\
\text { adequately de-roofing } \\
\text { chamber }-29.1 \% \\
\rightarrow \text { Gouging on the floor- } \\
18.9 \% \\
\rightarrow \text { Difficulty in locating } \\
\text { canals }-10.9 \% \\
\rightarrow \text { Difficulty in using Endo } \\
\text { Explorer }-8.3 \% \\
\rightarrow \text { Perforation }-7.7 \%\end{array}$} \\
\hline 2 & $\begin{array}{l}\text { Difficulty in } \\
\text { locating canals }\end{array}$ & $75(21.4)$ & $92(26.3)$ & $145(41.4)$ & $38(10.9)$ & \\
\hline 3 & $\begin{array}{l}\text { Difficulty in } \\
\text { using Endo } \\
\text { explorer (DG 16) }\end{array}$ & $29(8.3)$ & $137(39.1)$ & $155(44.3)$ & $29(8.3)$ & \\
\hline 4 & $\begin{array}{l}\text { Gouging on the } \\
\text { floor }\end{array}$ & $7(2.0)$ & $109(31.1)$ & $168(48.0)$ & $66(18.9)$ & \\
\hline 5 & Perforation & $105(30.0)$ & $162(46.3)$ & $56(16.0)$ & $27(7.7)$ & \\
\hline
\end{tabular}

Table 4: Working length related difficulty

\begin{tabular}{|c|c|c|c|c|c|c|}
\hline \multirow{2}{*}{\multicolumn{2}{|c|}{ QUESTIONS }} & \multicolumn{4}{|c|}{ DIFFICULTY GRADING \% } & \multirow{2}{*}{$\begin{array}{c}\text { DIFFICULTY } \\
\text { GRADING CRITERIA }\end{array}$} \\
\hline & & NEVER & RARELY & OCCASIONALLY & FREQUENT & \\
\hline 1 & \begin{tabular}{|l|} 
Difficulty to \\
reach original \\
working length
\end{tabular} & $6(1.7)$ & $91(26.0)$ & $199[56.9)$ & $54(15.4)$ & \multirow{3}{*}{$\begin{array}{l}\text { Maximum difficulty in } \\
\text { using apex locator - } \\
19.4 \% \\
\text { > Difficulty to reach } \\
\text { working length }-15.4 \% \\
\rightarrow \text { Difficulty to feel } \\
\text { apical constriction - } \\
1.1 \%\end{array}$} \\
\hline 2 & $\begin{array}{l}\text { Difficulty to } \\
\text { feel apical } \\
\text { constriction }\end{array}$ & $36(10.3)$ & $147(42.0)$ & $163(46.6)$ & $4(1.1)$ & \\
\hline 3 & $\begin{array}{l}\text { Difficulty using } \\
\text { apex locator }\end{array}$ & $38[10.9)$ & $110(31.4)$ & $134[38.3)$ & $68(19.4)$ & \\
\hline
\end{tabular}

most common mishap being apical perforation (51.4\%), loss of estimated WL (51.1\%), ledge formation (40.9\%), file separation (39.1\%), whereas using accessory GP while obturations were recorded as the most frequently encountered problem $(56 \%)$

(Table 6). Inability to control the master cone was seen as well where extrusion beyond apex was seen in $40 \%$ of the responses and short master cone was seen in $36.6 \%$ of the responses.
Table 5: Cleaning and shaping related difficulty

\begin{tabular}{|c|c|c|c|c|c|c|}
\hline \multirow{2}{*}{\multicolumn{2}{|c|}{ QUESTIONS }} & \multicolumn{4}{|c|}{ DIFFICULTY GRADING \% } & \multirow{2}{*}{$\begin{array}{c}\text { DIFFICULTY } \\
\text { GRADING CRITERIA }\end{array}$} \\
\hline & & NEVER & RARELY & OCCASIONALLY & FREQUENT & \\
\hline 1 & Ledge Formation & $20(5.7)$ & $85(24.3)$ & $102(29.1)$ & $143(40.9)$ & $\rightarrow$ Most common \\
\hline 2 & Apical Perforation & $5(1.4)$ & $30(8.6)$ & $135(38.6)$ & $180(51.4)$ & Perforation $-51.4 \%$ \\
\hline 3 & Zipping & $25(7.1)$ & $54(15.4)$ & $163(46.6)$ & $108(30.9)$ & $\mathrm{C} / \mathrm{S}-51.1 \%$ \\
\hline 4 & Canal Blockage & $13(3.7)$ & $89(25.4)$ & $114(32.6)$ & $134(38.3)$ & $40.9 \%$ \\
\hline 5 & File Separation & $18(5,1)$ & $87(24.9)$ & $108(30.9)$ & $137(39.1)$ & $\begin{array}{l}\text { > Difficulty in } \\
\text { achieving continuous }\end{array}$ \\
\hline 6 & Strip Perforation & $100(28.6)$ & $144(41.1)$ & $89(25.4)$ & $17(4.9)$ & $\begin{array}{l}\text { taper }-40.0 \% \\
\rightarrow \text { File Separation - }\end{array}$ \\
\hline 7 & Loss of WL during $C / S$ & $23(6.6)$ & $47(13.4)$ & $101(28.9)$ & $179(51.1)$ & $\begin{array}{l}39.1 \% \\
\rightarrow \text { Canal Blockage - }\end{array}$ \\
\hline 8 & Apical Transportation & $25(7.1)$ & $126(36.0)$ & $157(44.9)$ & $42(12.0)$ & $\begin{array}{l}38.3 \% \\
\rightarrow \text { Zipping }-30.9 \%\end{array}$ \\
\hline 9 & Flare Up & $143(40.9)$ & $162(46.3)$ & $40(11.4)$ & $5(1.4)$ & $\begin{array}{l}>\text { Apical } \\
\text { Transportation }-12 \%\end{array}$ \\
\hline 10 & $\begin{array}{l}\text { Difficulty in achieving } \\
\text { continuous taper } \\
\text { preparation }\end{array}$ & $8(2.3)$ & $71(20.3)$ & $131(37.4)$ & 14. $(40.0)$ & $\begin{array}{l}->\text { Strip Perforation - } \\
4.9 \% \\
\rightarrow \text { Flare Up - } 1.4 \%\end{array}$ \\
\hline 11 & $\begin{array}{l}\text { Sodium Hypochlorite } \\
\text { Accident }\end{array}$ & $150(42.9)$ & $167(47.7)$ & $25(7.1)$ & $8(2.3)$ & $\begin{array}{l}\rightarrow \text { Sodium Hypochlorite } \\
\text { Accident }-2.3 \%\end{array}$ \\
\hline
\end{tabular}

Table 6: Obturation related difficulty

\begin{tabular}{|c|c|c|c|c|c|c|}
\hline \multirow{2}{*}{\multicolumn{2}{|c|}{ QUESTIONS }} & \multicolumn{4}{|c|}{ DIFFICULTY GRADING \% } & \multirow{2}{*}{$\begin{array}{c}\text { DIFFICULTY } \\
\text { GRADING CRITERIA }\end{array}$} \\
\hline & & NEVER & RARELY & OCCASIONALLY & FREQUENT & \\
\hline 1 & $\begin{array}{l}\text { Difficulty in } \\
\text { application of sealer }\end{array}$ & $173(49.4)$ & $133(38.0)$ & $39(11.1)$ & $5(1.4)$ & \multirow{7}{*}{$\begin{array}{l}\rightarrow \text { Maximum difficulty } \\
\text { in using accessory GP- } \\
56.0 \% \\
\rightarrow \text { Master GP beyond } \\
\text { Apex }-40.0 \% \\
\rightarrow \text { Master GP short of } \\
\text { Apex }-36.6 \% \\
\rightarrow \text { Voids in Obturation } \\
8.3 \% \\
\rightarrow \text { No Tug Back }-3.4 \% \\
\rightarrow \text { Difficulty in } \\
\text { application of Sealer - } \\
1.4 \% \\
\rightarrow \text { Difficulty using } \\
\text { spreader }-0.9 \%\end{array}$} \\
\hline 2 & $\begin{array}{l}\text { Master GP short of } \\
\text { apex }\end{array}$ & $14(4.0)$ & $56(16.0)$ & $152(43.4)$ & $128(36.6)$ & \\
\hline 3 & $\begin{array}{l}\text { Master GP beyond } \\
\text { apex }\end{array}$ & $10(2.9)$ & $41(11.7)$ & $159(45.4)$ & $140(40.0)$ & \\
\hline 4 & No Tug back & $35(10.0)$ & $161(46.0)$ & $142(40.6)$ & $12(3.4)$ & \\
\hline 5 & $\begin{array}{l}\text { Difficulty using } \\
\text { spreader }\end{array}$ & $165(47.1)$ & $154(44.0)$ & $28(8.0)$ & $3(0.9)$ & \\
\hline 6 & $\begin{array}{l}\text { Difficulty using } \\
\text { accessory GP }\end{array}$ & $5(1.14)$ & $30(8.6)$ & $119(34.0)$ & $196(56.0)$ & \\
\hline 7 & Voids in Obturation & $9(2.6)$ & $161(46.0)$ & $151(43.1)$ & $29(8.3)$ & \\
\hline
\end{tabular}

\section{DISCUSSION}

Routine assessment and criticism from freshly graduated doctors is always encouraged by institutes in order to better themselves by making adjustments to their curriculum and teaching methods. In our study, house officers were asked to score the level of difficulty they each faced by answering 35 close-ended questions as shown in Figure.2. The difficulty criteria varied from 'never' to 'frequently' with a scale of 0-3 as shown in Figure.1.

Administration of local anesthesia is a routine dental practice when Endodontics is concerned. A pain free state ensures maximum comfort level of the patient which is the

Figure 1: The scale of difficulty

\begin{tabular}{|c|c|}
\hline \multicolumn{2}{|c|}{ DIFFICULTY GRADING CRITERIA } \\
\hline 0 & NEVER \\
\hline 1 & RARELY \\
\hline 2 & OCASSIONALLY \\
\hline 3 & FREQUENTLY \\
\hline
\end{tabular}


actual goal of all dental practices. However, the rate of failure of local anesthesia in the mandible is generally high and is one of the major problems that were faced by the house officers in our study. A thorough knowledge of the anatomical variations and meticulous skill is required for one to achieve absolute anesthesia. Failure of IANB has the highest rates in our study (48\%) and is the most technique sensitive method of administering local anesthesia. In most cases where irreversible pulpitis of mandibular teeth is concerned, there is failure of achieving a full anesthetic state with just an IANB and there is need for supplemental anesthesia. ${ }^{8}$

Causes of failure can be categorized as patient related and operator related. Patient factors usually include any pathology in the form of infection, inflammation, trismus or they may be psychological. Patient anxiety and needle phobia also lead to failure of anesthesia. ${ }^{9}$ Pre-operative pain can lead to a higher chance of failure of achieving complete anesthesia. ${ }^{10}$ However, patients with specific pathologies are rare and failure is more often seen as a fault from the operator's end. Since the house officers are only given practical exposure to local anesthesia during surgery and periodontology departments, many do not have the full skill set developed to achieve absolute anesthesia. Faulty placement of the needle, sudden changes in the direction of needle placement and inserting the needle too deep into the tissue folds are just some of the most common mistakes performed by house officers when administrating IANB. ${ }^{11,12}$ Inadequate mouth opening and failure to locate the pterygomandibular raphe also contribute to increased rates of failure of IANB. Due to the increased percentages of failure of IANB in our study, there was a higher percentage found for need of accessory means of anesthesia after IANB. ${ }^{13}$ Buccal infiltrations along with intra ligamentary anesthesia were given in cases where repeating the IANB was ineffective. ${ }^{14}$

In Table 2, which focused on patient related difficulties, it was seen that the major problems arose in time management, pain management and in patient counseling. It was observed that house officers having the highest number of root canal cases, as recorded by the responses of the survey( Fig.2), stated that over time and practice they were able to manage their time effectively. Since the house officers are fairly new to the procedures of root canal therapy on patients, they faced major problems in managing time they spent on each patient, a complication which arises initially but resolves with time and learned skill.

Pain management has been the second most troublesome job according to our study. Patients experiencing pulpal pathosis often have very low thresholds to anesthetic agents and achieving a complete sedative state is often troublesome. ${ }^{15}$ Failure to achieve local anesthesia is also dependent on the house officer skill ${ }^{16}$ and inaccurate technique of administration of Inferior Alveolar Nerve Block can also be a factor for the increased incidence of difficulty in pain management in this study. Administration of intra pulpal anesthetic solution, given at intervals has proved to be of use in cases with pulp hyperemia. ${ }^{17}$

In a multicultural society, it often becomes difficult for the health care providers to properly explain a certain medical condition or treatment plan, due to patients having a language barrier. Lack of knowledge of any particular treatment creates a level of anxiety and fear amongst the patient, resulting in it being a difficult situation for the doctor. In our study, we found that $31.4 \%$ of dental house officers faced trouble in patient counseling and it was observed that with time and increasing number of patients this problem was gradually reduced.

Table 3 was focused more on problems faced during access opening. The highest percentages of difficulties were assigned to improper de-roofing of the chamber, gouging and difficulty in location of canals. Inadequate knowledge of root canal morphology and tooth anatomy can cause such problems. ${ }^{18}$ As dental undergraduate students, they perform routine Endodontics on extracted teeth and each tooth is prepped according to standard guidelines. When the house officers start performing treatment on patients the complexity increases according to the position, angulation of bur in mouth and extent of caries, as a result they face greater difficulty.

Lack of visibility and incorrect chair positioning of the dentist are major reasons for this problem. Gouging occurs due to incorrect angulation of the bur and can result in weakening of the remaining tooth structure. It occurs simultaneously with incomplete de-roofing of the chamber and can be avoided by using a large round bur.

Table 4 concentrates on issues associated with working length determination. The maximum difficulty faced by dental house officers was in using the apex locators. Since introduction to apex locators is only done in the clinical setting after graduation many house officers have trouble using it. Early awareness of apex locators and their widespread use can solve this problem. ${ }^{19}$ Inability to follow the true path of the root canal or excessive calcifications can lead to increased difficulties in reaching the desired working lengths. ${ }^{20}$ Previous studies have shown a greater difficulty in determining the apical constriction however that was not the case in our study and only $1.1 \%$ of the total doctors found it hard to determine the apical constriction. ${ }^{7,21}$

Table 5 displays results of difficulties faced during the cleaning and shaping process. The highest percentages of difficulty was allotted to apical perforations, loss of working length, ledge formation, achieving continuous taper, file 
separation and canal blockage. Various other studies have previously stated that apical perforation is the leading cause of problems faced by dentists. ${ }^{17,22,23}$ When using stainless steel files, there are increased chances of loss of working length during cleaning and shaping, hence apical stop is usually missed leading to increased incidence of apical perforations. ${ }^{16}$ Radiographs taken by house officers also usually done using the non-parallel technique the bisecting angle technique which makes it harder for them to judge the actual working length via radiographs only. ${ }^{24,25}$ Loss of working length was commonly encountered by house officers as well since working length determination is done prior to cleaning and shaping and many stated that there was loss of working length when obturation was initiated. Crown-down technique of cleaning and shaping has been shown to be the most frequently used method by house officers, ${ }^{26}$ which leads to increased deposition of debris apically and failure to adequately recapitulate the canals results in loss of working length. Since stainless steel files are rigid in nature, when compared to NiTi rotary files, they tend to extrude through the apical constriction leading to loss of apical stop and eventually loss of required working length. ${ }^{27,28}$

In our study, ledge formation is another leading cause of loss of working length and is a major issue when house officers are concerned. There is a high percentage of ledge formation seen in our study (40.9\%) as compared to other studies which show similar results such as Haji-Hassani N et al 3.6\%, ${ }^{21}$ Reem Siraj Alsulaimani et al 34.5\%. ${ }^{29}$ Use of Gates Glidden burs are usually advised for coronal flaring of the canal orifice but this is not a common practice amongst house officers which tend to use larger number of $\mathrm{K}$ files for coronal flaring. ${ }^{30}$ These, along with the reduced use of EDTA as a lubricating medium, are the major causes of ledge formation. Although, pre-curving of files is advised, especially when treating molars with curved canals, due to the inflexible nature of stainless steel files there is increased ledge formation when using larger number of $\mathrm{K}$ files. ${ }^{31}$

Use of NiTi instruments has proven to be beneficial in reducing procedural errors when compared to stainless steel instruments. ${ }^{29}$ It is less time consuming, being more patient friendly ${ }^{32,33}$ and its flexible nature and excellent shape memory prove to be advantageous in cases with curved canals. ${ }^{34}$ However, NiTi instruments have not been accepted widely by many institutes due to increased cost and maintenance and their increased risk of fracture where NiTi rotary instruments are concerned. ${ }^{35}$ Many dentists have previously stated that repeated use of NiTi rotary files have resulted in fracture during cleaning and shaping and discarding the files after single use has been advantageous. ${ }^{36}$ This results in increased cost of using NiTi files.

Cleaning and shaping of the root canal is a tedious process and in order to speed up the procedure many house officers end up not giving proper attention to the methods, which results in loss of continuous taper of the canal. Incorrect sequencing of the files result in the preparation being flared apically but the middle third is left narrow. Proper sequencing of the files is mandatory to achieve a constant taper of the canal.

Over use of stainless steel instruments results in increased incidence of file separation as shown in our study $39.1 \%$. A study conducted by Alhekeir, et $\mathrm{al}^{17}$ showed a similar result of broken instruments $(31.8 \%)$ while Mothanna K. AlRahabi $(9.2 \%)^{7}$, Haji-Hassani $\mathrm{N}$ et al $(1.1 \%)^{21}$ and Alsulaimani

RS et al. ${ }^{29}(1.8 \%)$ had lower rates of such accidents. Incorrect angulation of the files along with increased apical pressure makes these files more prone to breakage. This issue can be solved by ensuring the canal is patent and by constant recapitulation in order to remove any debris present apically so that the files do not get lodged or break. Teeth having chronic infections tend to get calcified over time, a problem commonly faced by house officers. ${ }^{37,38}$ Another reason for blocked canals is the failure of house officers to recapitulate the canals leading to heavy packing of debris apically. ${ }^{39}$

Table 6 discusses difficulties routinely faced during obturation. The maximum difficulty was seen in using accessory GP which is mainly due to problems house officers face in visualization of the canal orifice once the master GP has been inserted. Gutta purcha of the smaller size tend to be very thin and more prone to bending which creates additional problems for the operator. Due to problems faced by house officers in determining the actual working length of the canal during cone fit radiographs there is a higher percentage of extrusion of the Master GP beyond the apex (40\%) as compared to the Master GP being short of the actual apex (36.6\%) in our study.

In order to counteract many of these problems it is recommended that the student to supervisor ratio should be increased in order to prevent mishaps occurring due to lack of knowledge of procedure. Certain changes in the curriculum are required to give undergraduate students adequate experience to use new techniques and methods along with the conventional methods. Use of NiTi rotary instruments can lead to prevention of many errors caused due to the rigid nature of stainless steel instruments. It is also suggested that proper evaluation of the teeth under consideration for endodontic treatment should be done prior to giving the case to a house officer.

Adequate supervision along with better guidance at each step of root canal treatment and use of more flexible instruments into the curriculum and preclinical labs can help to combat such issues in future. 


\section{CONCLUSION}

The current study displays the most commonly faced difficulties by fresh dental graduates during their house job. Cleaning and shaping is the major difficulty faced by the house officers in achieving endodontic excellence. Difficulty in achieving IANB leads to higher percentage of accessory means of local anesthesia. A higher number of cases have revealed gutta purcha either beyond or short of the apex.

\section{CONFLICT OF INTEREST}

None declared.

\section{REFERENCES}

1. Fejerskov O, Kidd E. Dental caries: the disease and its clinical management: John Wiley \& Sons; 2009.

2. Ng YL, Mann V, Rahbaran S, Lewsey J, Gulabivala K. Outcome of primary root canal treatment: systematic review of the literaturePart 2. Influence of clinical factors. Int Endod J. 2008; 41(1):6-31.

3. Chugal N, Lin LM, Kahler B. Introduction: Endodontic Prognosis and Outcome. Endodontic Prognosis: Springer; 2017. p. 1-12. https://doi.org/10.1007/978-3-319-42412-5

4. Lanning SK, Wetzel AP, Baines MB, Byrne BE. Evaluation of a revised curriculum: A four-year qualitative study of student perceptions. J Dent Educ. 2012; 76(10):1323-33.

5. Mozayeni MA, Asnaashari M, Modaresi SJ. Clinical and radiographic evaluation of procedural accidents and errors during root canal therapy. Iran Endod J. 2006; 1(3):97-100.

6. Chatzopoulos GS, Koidou VP. Oral hygiene and nutrition habits of young people in Greece aged 18 to 25 and review of the literature. Balk J Dent Med. 2014; 18(3):133-43.

https://doi.org/10.1515/bjdm-2015-0021

7. AlRahabi MK. Evaluation of complications of root canal treatment performed by undergraduate dental students. Libyan J Med. 2017; 12(1):1345582.

https://doi.org/10.1080/19932820.2017.1345582

8. Kanaa MD, Whitworth JM, Meechan JG. A prospective randomized trial of different supplementary local anesthetic techniques after failure of inferior alveolar nerve block in patients with irreversible pulpitis in mandibular teeth. J Endod. 2012; 38(4):421-5.

https://doi.org/10.1016/j.joen.2011.12.006

9. Bassett KB, DiMarco AC, Naughton DK. Local anesthesia for dental professionals: Boston; 2015.

10. Andreasen FM, Kahler B. Pulpal response after acute dental injury in the permanent dentition: clinical implications-a review. J Endod. 2015; 41(3):299-308.

https://doi.org/10.1016/j.joen.2014.11.015
11. Kotze M, Labuschagne W. Evaluation of two different-gauge dental needles for the presence of blood following the application of local anesthesia by dental students. SADJ. 2015; 70(1):17-21.

12. Hochman MN, Friedman MJ. In vitro study of needle deflection: a linear insertion technique versus a bidirectional rotation insertion technique. Quintessence Int. 2000; 31(1).

13. Bidar M, Moradi S, Forghani M, Bidad S, Azghadi M, Rezvani $\mathrm{S}$, et al. Microscopic evaluation of cleaning efficiency of three different Nickel-titanium rotary instruments. Iran Endod J. 2010; 5(4):174.

14. Aggarwal V, Singla M, Miglani S, Kohli S, Sharma V, Bhasin S. Does the volume of supplemental intraligamentary injections affect the anaesthetic success rate after a failed primary inferior alveolar nerve block? A randomized?double blind clinical trial. Int Endod J. 2018; 51(1):5-11.

https://doi.org/10.1111/iej.12773

15. Smith GN, Smith SA. Intrapulpal injection: distribution of an injected solution. J Endod. 1983; 9(5):167-70.

https://doi.org/10.1016/S0099-2399(83)80088-0

16. Lin S, Wigler R, Huber R, Kaufman AY. Anaesthetic efficacy of intraligamentary injection techniques on mandibular molars diagnosed with asymptomatic irreversible pulpitis: A retrospective study Aust Endod J. 2017; 43(1):34-7.

https://doi.org/10.1111/aej.12169

17. Alhekeir DF, Al-Sarhan RA, Mokhlis H, Al-Nazhan S. Endodontic mishaps among undergraduate dental students attending King Saud University and Riyadh Colleges of Dentistry and Pharmacy.SEJ. 2013;3(1):25.

https://doi.org/10.4103/1658-5984.116277

18. Boopathi T, Sebeena M, Sivakumar K, Harikaran J, Karthick K, Raj A. Supplemental pulpal anesthesia for mandibular teeth. J Pharm Bioallied Sci. 2013;5(Suppl 1):S103.

https://doi.org/10.4103/0975-7406.113307

19. Gordon MPJ, Chandler NP. Electronic apex locators. Int Endod J, 37, 425-437, 2004.

https://doi.org/10.1111/j.1365-2591.2004.00835.x

20. Jafarzadeh H, Abbott PV. Ledge formation: review of a great challenge in endodontics. J Endod . 2007;33(10):1155-62. https://doi.org/10.1016/j.joen.2007.07.015

21. Haji-Hassani N, Bakhshi M, Shahabi S. Frequency of iatrogenic errors through root canal treatment procedure in 1335 charts of dental patients. JIOH. 2015;7(Suppl 1):14.

22. Vongsavan K, Samdrup T, Kijsamanmith K, Rirattanapong P, Vongsavan N. The effect of intraosseous local anesthesia of $4 \%$ articaine with 1: 100,000 epinephrine on pulpal blood flow and pulpal anesthesia of mandibular molars and canines. Clin Oral Investig. 2018:1-8. https://doi.org/10.1007/s00784-018-2481-3

23. Walsch H. The hybrid concept of nickel-titanium rotary instrumentation. Dent Clin North Am. 2004;48(1):183-202. 
https://doi.org/10.1016/j.cden.2003.11.003

24. Raoof M, Heidaripour M, Shahravan A, et al. General Dental Practitioners' Concept towards Using Radiography and Apex-Locators in Endodontics . Iran Endod J. 2014;9(4):277-282.

25. Waplington M, McRobert A. Shaping the root canal system. BDJ Open. 2014;216(6):293.

https://doi.org/10.1038/sj.bdj.2014.203

26. Lambrianidis T, Mazinis E. Parameters Influencing the Removal of Fractured Instruments. Management of Fractured Endodontic Instruments: Springer; 2018. p. 197-206.

https://doi.org/10.1007/978-3-319-60651-4_5

27. Altunbas D, Akpinar Ke, Kustarci A. An in vitro study of the effects of different torque values applied to the nickel titanium rotary canal instruments for curved root canal preparation. Atatürk Üniversitesi Dis Hekimligi Fakültesi Dergisi. 2015;25(2)172-80.

28. Hülsmann M, Schade M, Schäfers F. A comparative study of root canal preparation with HERO 642 and Quantec SC rotary Ni-Ti instruments. Int Endod J. 2001;34(7):538-46.

https://doi.org/10.1046/j.1365-2591.2001.00431.x

29. Alsulaimani R, Almanei K, Abbtain R, Binrabba R, Ashri N. The Correlation between Endodontic Mishaps and Single-Visit Treatment in King Saud University. Int J Dent Oral Health. 2016;3(1).

30. Jeevanandan G, Thomas E. Volumetric analysis of hand, reciprocating and rotary instrumentation techniques in primary molars using spiral computed tomography: An in vitro comparative study. Eur J Dent. 2018;12(1):21-26.

https://doi.org/10.4103/ejd.ejd_247_17

31. Fallatah HY, El Sherief SM. Cone-beam computed tomography analysis of centering ability and transportation of curved root canals prepared with three rotary nickel-titanium systems (In Vitro-Study). IJS Short Reports. 2018;3(1):58-64.

https://doi.org/10.4103/ijssr.ijssr_21_17
32. Hema B, Chandu G, Shiraguppi V. Scanning electron microscopic evaluation of root canal surfaces prepared with three rotary endodontic systems: Lightspeed, ProTaper and EndoWave. Niger J Clin Pract. 2015;18(1):130-6.

33. Mozayeni MA, Golshah A, Kerdar NN. Endod J. 2011;6(4): 168-75.

34. Elemam R. Assessment of the root canal transportation after preparation with newly introduced endodontic files: Universidade do Porto (Portugal); 2016.

35. afarzadeh $\mathrm{H}$, Abbott PV. Ledge formation: review of a great challenge in endodontics. J Endod. 2007;33(10):1155-62.

https://doi.org/10.1016/i.joen.2007.07.015

36. Ferreira ACG, Frozoni M, Prado M, Gomes B, Signoretti F, DeJesus-Soares A. Current trends in technological armamentarium and treatment among Brazilian endodontists. Braz J Oral Sci. 2017;16:110 .

https://doi.org/10.20396/bjos.v16i0.8650494

37. Stanley HR.et al: The detection and prevalence of reactive and physiologic sclerotic dentin, reparative dentin and dead tracts beneath various types of dental lesions according to tooth surface and age, J Oral Pathol. 1983;12:257-89.

https://doi.org/10.1111/j.1600-0714.1983.tb00338.x

38. Problem Solving in Endodontics, 4th ed. Mosby 2006,James L.Gutmann,Thom C. Dumsha, Paul E.Lovdahl : p 115-116

39. Boutsioukis C, Lambrianidis T, Verhaagen B, Versluis M, Kastrinakis E, Wesselink $\mathrm{P}$, et al L. The effect of needle-insertion depth on the irrigant flow in the root canal: evaluation using an unsteady computational fluid dynamics model. J Endod. 2010;36 (10):1664-8. https://doi.org/10.1016/j.joen.2010.06.023 